\title{
Appraisal of Community Involvement in Secondary Schools Development in Okigwe Education Zone of Imo State
}

\author{
Emenalo, F.C. \\ Camillus Ibekwe \\ Dept of Educational Foundations and Administration, \\ Faculty of Education, \\ Imo State University, Owerri-Nigeria
}

\section{Doi:10.5901/mjss.2013.v4n7p13}

\section{Abstract}

The study appraised Community involvement in Secondary School development in Okigwe Education Zone: Descriptive and inferential survey design was adopted for the study. The total population of 156 respondents, i.e. Principals and Chairmen of Board of Governors (BOGs) of Senior Secondary Schools (SSS) were used without sampling. Data were collected using a 20- item researchers made questionnaire, with response options of $S A$, $A, D, S D$. Four research questions and two hypotheses were used. Mean scores $(X)$ of 2.50 were used to answer the research questions while $Z$ - test statistics tested the hypotheses at 0.05 level of significance. The results show that, Communities in Okigwe Zone get involved on the development of their secondary schools through donation of lands, donation of money and payment of school fees for their children in the schools, they equally construct school buildings, provide facilities such as science and sports equipment, library facilities etc. It further revealed that the Communities do not monitor to ensure proper utilization of funds made available to the schools, launching and PTA levies are the major strategies Communities use in rasing funds for their schools etc. In the light of these, recommendations were made that Communities should not relax in their effort of school development after their initial involvement in setting up the schools; Principals should develop and adopt good school Community relationship strategies to attract assistance from the community, and have to ensure proper utilization and maintenance of the available school resources. etc.

\section{Introduction}

Human and societal development is dependent on the level of educational attainment of the people. Hence, education has been accepted globally as an instrument for national development and transformation (FRN 2004). Education has intrinsic and extrinsic values to both the individuals and the society at large. This is stressed by Ohaeri, (2009) that

no element of national life is more worthy of attention, support and concern than education, for no element has greater impact on the careers, personal growth and happiness of many citizens. No element is of greater importance improving the knowledge and leadership on which the vitality of democracy and strength of national economy depends (P.2).

In view of the great importance attached to education with regard to national and individual life, it is imperative that all hands must be on deck to ensure that the necessary resources for effective development and management of education are provided. As noted by Asodike (2008), the involvement of communities in the management of education in Nigeria is not new in the system. It dates back to the colonial period when the administrators made use of the local communities in the provision and furtherance of western education. For instance, parents provided money in cash and kind, local communities gave out their lands with labour for 
the development of education, provided guards for safety of materials in use, and free accommodation for the missionaries in the community, all in the effort to contribute to the basic needs, for the development of education. He therefore opined that education being an expensive social service requires the efforts of the different segments of the society to attain its goals and objectives.

There is no doubt that education, no matter the level, is capital intensive. Funds are needed to procure and provide teaching and learning equipment, materials, construct buildings and other school plant as well as human and other information and communication technology gadgets. This account for Nigerian government's continuous clarion calls for private participation in providing education for the citizenry. This is clearly expressed in the National Policy on education (2004), that education is an expensive social service that requires adequate financial provisions from all tiers of government for successful implementation of educational programmes. It further states that financing of education is a joint responsibility.

Secondary education in Nigeria is that level of education after the primary education. Secondary education is a link between the Primary and the Tertiary levels of education. The essence of secondary education is to prepare its recipients for useful living within the society and for higher education. It has two segments in Nigeria, Junior and Senior levels. The Junior secondary segment where UBE is mainly housed attracts much government attention, but the senior secondary section which is the focus of the study does not have much of such attention. Some of these secondary schools are located in the urban areas while some are in the rural areas. However, no matter the location of these schools, they are situated within communities and students are drawn from such communities. This calls for a symbiotic and a reciprocal relationship that would result in the promotion of educational development, with its attendant individual and national growth, development and transformation. Historically, most communities in Imo State had recognized and appreciated their responsibilities in contributing to the development of secondary education before now; hence they embarked on the construction of school buildings, giving scholarship to brilliant children, providing labour to schools etc. Most secondary schools in rural areas today were built through community efforts and handed over to government.

But in recent times, it seems that most communities have started relaxing, showing little interest in contributing to secondary school development. No wonder Federal government emphasis on the role of communities in the management and development of her educational system. School communities include Parents Teachers Association (PTA), Board of Governors (BOG), Religious organizations, Town Unions, Alumni Association, Business Organizations. These bodies are required to get involved and fund the development of secondary education. Ogbonnoya (2000) noted this when he opined that

Funding is a critical issue in the Nigeria educational system... various arms of government and their agencies cannot provide all the funds needed for education. Therefore, the funding of education should be a combined responsibility of Federal, State, and Local governments, and Local Communities (P. 30).

Subscribing to the communities participation in school development, Maduewesi (2007) in Ibekwe (2012) pointed out that no school can operate effectively without community interest, understanding and participation, since the community supplements the educational opportunities offered within the community. Similarly, Akindele, (2000) stated that the achievement of effective and efficient education for Nigerians in the foreseeable future should come from increased participation of Community and Private sector.

Community involvement in secondary education development could take different forms since it will be unrealistic to leave the development of Secondary School Education to government alone. This involvement could also be at different rate and pace viz a viz the peculiarities of a given Community. This could account for the absence or lack of facilities, Teachers, and a general dilapidated state of Secondary Schools in certain Communities. 


\section{Statement of the Problem.}

The general deplorable state of education in Nigeria has been of great concern to all and sundry. From the Primary to the Tertiary level, it is a tale of woes; the whole system seems to be in the verge of collapse. Secondary schools which provide the link between Primary and Tertiary levels of education seem to suffer serious neglect especially in Okigwe zone. Most schools have inadequate and dilapidated buildings, lack meaningful libraries, scientific facilities and equipments, computers, with inadequate, and demoralized Teachers, and general lack of discipline among the Teachers and Students. Most of these observed problems have been attributed to lack of funds in the schools. One begins to wonder what Communities are doing to help in view of the facts that some of these schools which were built through the Community efforts, and whether government continuous clarion calls for public private partnership due to heavy capital intensive nature of education is yielding any positive result?

However, one does not loose sight of the fact that poverty or financial state of most people or community could influence community involvement in secondary school development. Okigwe zone being made up of mainly peasant farmers with little urbanization, what is the involvement of the communities in secondary school development. Be that as it may, communities ought not be on the fence watching these secondary schools where their children are being trained and moulded to rot away, without quality education especially now that government pays much attention on Junior Secondary Schools due to the Universal Basic Education Programme (UBE) In the light of these situations, the researchers are agitated to have an appraisal of the involvement of communities in Okigwe Educational Zone in Senior Secondary school development.

\section{Purpose of the study}

The main purpose of the study is to ascertain the Communities' involvement in Senior Secondary Schools development in Okigwe Education Zone of Imo State.

Specifically, the study aims to achieve the following objectives:

1. To ascertain whether Communities sponsor certain projects in Secondary Schools in Okigwe Zone.

2. To examine how Communities are involved in monitoring the utilization of funds provided for the running of Schools.

3. To find out ways Communities assist secondary schools in the provision of facilities in Okigwe Zone.

4. To find out strategies Communities use in raising funds for developing secondary schools in Okigwe Zone.

\section{Research Questions}

To guide the study, the following research questions are posed.

1. What is the involvement of Communities in developing, Secondary Schools in Okigwe Education Zone?

2. How do Communities ensure proper utilization of funds provided for the running of Secondary School?

3. In what ways do Communities assist Secondary Schools in the provision of facilities?

4. What strategies do communities use in raising funds for Secondary Schools development in Okigwe Zone? 


\section{Hypotheses}

1. There is no significant difference between the Mean scores of Principals and Board of Governors of Senior Secondary Schools in Okigwe Education Zone in Community involvement in the funding of Senior Secondary Schools at 0.05 level of significance.

2. There is no significant difference between the Mean scores of Principals and Chairmen Board of Governors of Senior Secondary Schools in Okigwe Zone in Community involvement in the provision of facilities for Senior Secondary Schools (P.<.0.05)

\section{Methodology}

The study adopted a descriptive and inferential survey research to ascertain Community involvement in Secondary School development in Okigwe zone. A Population of 78 Secondary School Principals and 78 Chairmen of Board of Governors (BOG) of all the 78 Secondary schools were used; this gives a total Population of 156 respondents. No sampling was drawn since the Population was small and could be conveniently handled. A 20 - item researchers made questionnaire with four- point modified Likert rating scale of strongly agreed (SA), Agreed (A) and Disagreed (D) strongly disagreed (SD) was used to collect data from the respondents. The instrument was validated through Peers review and the reliability co -efficient of 0.76 was derived by administering the questionnaire twice at two weeks interval to five Principals and five Chairmen of Board of Governors outside the zone of the study, using Pearson product moment correlation statistics.

The instrument was personally administered to the Principals who in turn assisted in giving the BOG Chairmen their questionnaire, since they do not frequent the school. Mean scores were used to answer the research questions. The Mean score of 2.50 and above was used as a bench mark. Any score below 2.50 was seen as rejecting the item. Z-test was used to test the null hypotheses at 0.05 level of significance.

\section{Results}

Results of the findings are presented in Tables 1, 2, 3, 4, 5 and 6.

Table 1: Mean ratings of Principals and BOG Chairmen on Community involvement in funding Senior Secondary Schools in Okigwe Zone.

\begin{tabular}{|c|l|c|c|c|c|c|c|}
\hline $\begin{array}{l}\text { S/ } \\
\mathrm{N}\end{array}$ & Item statement & Principals & & & B O G & & \\
\hline & & EFX & X & Remarks & EFX & X & Remarks \\
\hline 1 & $\begin{array}{l}\text { Communities donate money to Senior } \\
\text { Sec Schls to enhance their funding }\end{array}$ & 126 & 3.28 & Positive & 126 & 3.75 & Positive \\
\hline 2 & $\begin{array}{l}\text { Host Communities of Secondary } \\
\text { Schools pay School fees for their } \\
\text { children }\end{array}$ & 126 & 3.85 & Positive & 126 & 3.15 & Positive \\
\hline 3 & $\begin{array}{l}\text { Communities hire Secondary Schools } \\
\text { facilities to enable them raise fund. }\end{array}$ & 100 & 1.67 & Negative & 150 & 3.75 & Positive \\
\hline 4 & $\begin{array}{l}\text { Host Communities buy Secondary } \\
\text { Schools farm produce to help them } \\
\text { generate fund. }\end{array}$ & 150 & 2.05 & Negative & 115 & 3.75 & Positive \\
\hline 5 & $\begin{array}{l}\text { Communities donate land to Secondary } \\
\text { Schools for building projects }\end{array}$ & 115 & 3.78 & Positive & 135 & 2.88 & Positive \\
\hline & Pooled mean & 2.92 & & & 3.11 & \\
\hline
\end{tabular}


The data on Table 1 show that both the Principals and BOG Chairmen are in positive agreement with items nos. 1, 2, and 5, which means that Communities in Okigwe Zone donate money to Secondary Schools, pay School fees of their children and donate lands for building projects. This is deduced from the recorded high Mean scores that are above 2.50. However, both respondents disagreed on item no 3, that Communities hire school facilities to enhance school fund while item no. 4 records discordant Mean score of 2-05 for Principals and 2.88 for BOG's that Communities buy Secondary School farm produce to help generate funds for schools.

Table 2. Mean scores of Principals and BOG's on Community monitoring of Secondary School funds utilization.

\begin{tabular}{|c|l|c|c|c|c|c|c|}
\hline S/N & Item statement & Principals & & & BOG & & \\
\hline & \multicolumn{1}{|l}{ EFX } & X & Remarks & EFX & X & Remarks \\
\hline 6 & $\begin{array}{l}\text { Host Communities allow Principals } \\
\text { free hands in utilizing funds made } \\
\text { available by them }\end{array}$ & 145 & 2.42 & Negative & 111 & 2.78 & Positive \\
\hline 7 & $\begin{array}{l}\text { Communities include their members } \\
\text { in monitoring projects in Secondary } \\
\text { Schools }\end{array}$ & 104 & 1.73 & Negative & 97 & 2.42 & Negative \\
\hline 9 & $\begin{array}{l}\text { Influential Communities members } \\
\text { determine how monies for projects } \\
\text { are spent }\end{array}$ & 102 & 1.07 & Negative & 90 & 2.25 & Negative \\
\hline $\begin{array}{l}\text { Parent Teachers Associations take } \\
\text { part in auditing Secondary Schools } \\
\text { account }\end{array}$ & 150 & 2.72 & Positive & 118 & 2.95 & Positive \\
\hline 10 & $\begin{array}{l}\text { Communities give money for specific } \\
\text { projects }\end{array}$ & 106 & 1.76 & Negative & 77 & 1.93 & Negative \\
\hline & Pooled mean & 2.06 & & & 2.47 & \\
\hline
\end{tabular}

The data on table two clearly show low Mean scores of both the Principals and the BOG's on items 7, 8, and 10, but both agreed on item no. 9 with the Mean scores of 2.72 and 2.95 respectively. This implies that the PTA members take part in auditing Secondary School Account. Item no. 6. recorded a disagreement between the Principals $(x=2.42)$ and the BOG's $(x=2.78)$, on Communities giving Principals free hands to make use of the funds made available to Secondary Schools. The other three items with low Mean scores below the 2.50 decision point and the Pooled Mean scores of 2.06 for Principals and 2.47 for BOG's indicate that Communities do not make efforts to ensure proper utilization of funds made available to Principals for school projects.

Table 3. Mean ratings of Principals and BOG's on Communities assistance in provision of facilities to Secondary Schools

\begin{tabular}{|c|l|c|c|c|c|c|c|}
\hline S/N & Item statement & Principals & & & BOG & & \\
\hline 11 & $\begin{array}{l}\text { Communities build classroom blocks for } \\
\text { secondary schools }\end{array}$ & 141 & 3.29 & Positive & 141 & 3.52 & Positive \\
\hline 12 & $\begin{array}{l}\text { Philanthropic members of the } \\
\text { community provide sciences equipment } \\
\text { for secondary schools }\end{array}$ & 131 & 3.27 & Positive & 131 & 3.27 & Positive \\
\hline 13 & $\begin{array}{l}\text { Parent teachers Associations provide } \\
\text { computers for secondary schools }\end{array}$ & 136 & 2.72 & Positive & 136 & 3.04 & Positive \\
\hline
\end{tabular}




\begin{tabular}{|c|l|c|c|c|c|c|c|}
\hline 14 & $\begin{array}{l}\text { Alumni Associations erect libraries for } \\
\text { their almamater }\end{array}$ & 125 & 2.78 & Positive & 125 & 3.12 & Positive \\
\hline 15 & $\begin{array}{l}\text { Town unions donate sporting facilities } \\
\text { to secondary schools }\end{array}$ & 139 & 3.08 & Positive & 139 & 3.47 & Positive \\
\hline & Pooled Mean & 3.08 & & & & 3.28 & \\
\hline
\end{tabular}

It is glaringly clear from the data on Table 3, that both the Principals and the BOG's strongly affirm that Communities assist in the provision of facilities in schools. This is exemplified by the high Mean ratings of both respondents in all the items nos 11 to 15 , with agreement Mean scores of 3.29/3.52, 3.27/ 3.27, 2.72/ $3.04,2.78 / 3.2$ and 3.08/3.47 respectively.

Table 4: Mean ratings of Principals and BOGs on Communities' strategies in raising funds for Senior Secondary Schools in Okigwe Education Zone.

\begin{tabular}{|c|c|c|c|c|c|c|c|}
\hline $\mathrm{S} / \mathrm{N}$ & Item statement & Principals & & & $\mathrm{BOG}^{\mathrm{s}}$ & & \\
\hline & & EFX & $x$ & Remarks & EFX & $x$ & Remarks \\
\hline 16 & $\begin{array}{l}\text { Communities build classroom blocks } \\
\text { for secondary schools }\end{array}$ & 150 & 2.50 & Positive & 101 & 2.52 & Positive \\
\hline 17 & $\begin{array}{l}\text { Philianthic members of the community } \\
\text { provide science equipment for } \\
\text { secondary schools }\end{array}$ & 119 & 1.98 & Negative & 121 & 3.02 & Positive \\
\hline 18 & $\begin{array}{l}\text { Parent Teachers Associations erect } \\
\text { libraries for their almamater }\end{array}$ & 142 & 2.36 & Negative & 138 & 3.45 & Positive \\
\hline 19 & $\begin{array}{l}\text { Town union donate sporting facilities to } \\
\text { secondary schools. }\end{array}$ & 141 & 2.35 & Negative & 146 & 3.65 & Positive \\
\hline 20 & $\begin{array}{l}\text { Parent teachers Associations Levy } \\
\text { student to raise fund for secondary } \\
\text { schools }\end{array}$ & 150 & 3.28 & Positive & 150 & 3.09 & Positive \\
\hline & Pooled mean & & 2.49 & & & 3.15 & \\
\hline
\end{tabular}

The high Mean ratings for items nos: 16 and 20 by the Principals and BOG's respectively, attest that organization of launchings and imposition of PTA levy on students are the main strategies Communities use in raising funds for Senior Secondary Schools in Okigwe Zone. The Principals did not accept Communities levying taxable adults, donations from wealthy members of the Community, seeking financial assistance from government, as strategies for raising funds for Senior Secondary Schools. But the BOG's responded on the affirmative on these strategies with Mean scores of 3.02, 3.45 and 3.65 for the said items nos. 17, 18 and 19.

Table 5: Z - test comparism of Mean ratings of Principals and Chairmen of BOG's on Community involvement in funding Secondary Schools in Okigwe Zone.

\begin{tabular}{|l|c|c|c|c|c|c|c|c|}
\hline Variation & $\mathrm{N}$ & $\mathrm{X}$ & $\mathrm{S}$ & $\mathrm{DF}$ & Z-cal & Z-critl & Prob & Decision \\
\hline Principals & 60 & 2.92 & -0.6264 & 98 & 0.385 & 1.96 & 0.05 & Accept \\
\hline $\begin{array}{l}\text { Chairmen, Board of } \\
\text { Governors }\end{array}$ & 40 & 3.11 & -0.3589 & & & & & \\
\hline
\end{tabular}

The data presented on Table 5, after analysis revealed that z-calculated of 0.385 is lees than the Z-critical of 1.96 with 98 degree of freedom at 0.05 significant level. Therefore the null hypothesis that, there is no significant difference between the Mean ratings of Principals and Chairmen, of Board of Governors on Community involvement in funding senior secondary schools in Okigwe zone is accepted. 
Table 6: z- test comparism of Principals and Chairmen of BOGs on Community involvement in the provision of facilities for Senior Secondary School (<P.0.05)

\begin{tabular}{|l|c|c|c|c|c|c|c|c|}
\hline Variation & $\mathrm{N}$ & $\mathrm{X}$ & $\mathrm{S}$ & $\mathrm{DF}$ & Z-cal & Z-critl & Prob & Decision \\
\hline Principals & 60 & 3.03 & -0.248 & 98 & 0.858 & 1.96 & 0.05 & Accept \\
\hline $\begin{array}{l}\text { Chairmen, Board of } \\
\text { Governors. }\end{array}$ & 40 & 3.280 & .177 & & & & & \\
\hline
\end{tabular}

In table 6 , the calculated Z-value of 0.858 is less than the critical value of 1.96 with 98 degree of freedom at 0.05 significant level. Therefore the null hypothesis is accepted. That is, there is no significant difference between the Mean ratings of principals and chairmen of BOGs on Communities' involvement in provision of facilities for Senior Secondary Schools in Okigwe Zone.

\section{Discussion of findings}

The study which sets out to appraise the Community involvement in Senior Secondary School development in Okigwe Zone of Imo State revealed that, Communities in Okigwe Zone get involve in Secondary Schools development through donation of money, payment of school fees and donation of lands. Hence Ogbonnaya (2008) earlier stated that funding of education is a combined responsibility of Federal, State, Local Government and the Local Communities.

It further established that Communities provide facilities to schools such as construction of buildings, provision of science equipment, computers, sporting and library facilities. This finding subscribe to the views of Nwadianu (2000 and) Asodike (2008) in Ibekwe (2012) that Communities have raised funds, erected buildings and equipped schools for government to take over. The worry is, if Communities are providing all these, why is the present observed inadequacy and, or the dilapidated physical facilities in Secondary Schools in Okigwe Zone? Could it be that Communities suspend, withdraw or reduce their support to Schools after their initial involvement in the establishment of the schools? These are issues to be looked into.

The study also found that why Communities get involved in the development of Secondary Schools, they do not make extra efforts to ensure proper utilization of funds made available for Schools project. The only area the Communities get involved in checkmating funds management is PTA members taking part in auditing school account, which is postmeton. This could account why Communities, many at times suspect and allege that principals in their schools embezzle school funds. This often results in incessant petitions to the Ministry of Education requesting for the transfer of such principals.

Regarding the strategies for raising funds for Secondary Schools in Okigwe Zone, the study revealed that both respondents agreed that launching and PTA levies are the major strategies Communities use to raise funds for schools. However, while the chairmen of BOGs agreed that taxation of adult members of the Communities, donations from wealthy sons and daughters and seeking financial assistance from government are other sources of raising funds for their schools, the principals did not accept them as strategies: Analyzing this discordant positions, one would say that since the principals are not full members of the Community, they may not be aware of some of the fund raising strategies Communities adopt. Also if wealthy sons and daughters of the Communities donate money to the schools, the principals have to be on the know. Nevertheless, what matters is that Communities have to diversify their strategies to raise funds for schools.

\section{Conclusion}

Community involvement in school development (Secondary) is a cherished age long practice in Imo State and Okigwe Zone in particular, and that needs to be sustained. The continuos clarion calls by the Federal Government of Nigeria for public private partnership in education development and sponsorship need not to 
be overlooked. All hands must be on deck to ensure that schools especially Senior Secondary Schools are continuously provided for, maintained and managed for a sustainable quality education.

\section{Recommendations}

Based on the findings of the study, the following recommendations are made:

1. Communities' participation in school development should not be relaxed after their initial involvement in setting up the schools. It has to be a continuous exercise for the maintenance and sustainability of quality in education.

2. Wealthy individuals in the communities need to make meaningful and positive contributions to the upliftment of the schools.

3. Principals of Secondary Schools should adopt good school community relationship strategies to attract important and wealthy personalities that will assist the schools.

4. Principals should ensure proper utilization and maintenance of available school

5. resources to avoid waste in the face of the economic stress staring everybody on the face.

\section{References}

Akindele, O.O (1990) The Public School System in the new Nigeria. its quality, standard, effectiveness and efficiency. Fafunwa Educational Foundation Lecture Ibadan: Welzilore Press

Asodike, J.D. (2008) Towards virile Parents and Community involvement in the management of Education for sustainable development. In J.B. Bababla, G.O. Akpan, I. Hauwa \&.A. O Ayeni (eds) Managing Education for sustainable development in developing Countries. Ibadan: His Lineage Publishing Ltd.

Federal Republic of Nigeria (2004) National Policy on Education. Lagos: Nigeria Education Research and Development Council (NERDC)

Ibekwe, C.C (2012) Extent of Community participation in the development of Secondary Schools in Okigwe Education Zone. Unpublished Masters Degree Thesis presented to the Faculty of Education, Imo State University, Owerri.

Ogbonna, N.O (2000) Foundations of Education Finance. Onitsha: Publishers International Ltd

Ohaeri, N.A. (2009) Evaluation of Community Involvement in the raising of funds for Secondary Schools in Imo State of Nigeria. Unpublished Masters Thesis of University of Nigeria, Nsukka. 